"Reflections on the prospects for democracy in Africa and on the impediments to that happening"

\begin{tabular}{|c|c|}
\hline AUTHORS & David Schultz (D http://orcid.org/0000-0001-7863-8694 \\
\hline ARTICLE INFO & $\begin{array}{l}\text { David Schultz (2019). Reflections on the prospects for democracy in Africa and } \\
\text { on the impediments to that happening. Development Management, 17(2), 26-36. } \\
\text { doi:10.21511/dm.17(2).2019.04 }\end{array}$ \\
\hline DOI & http://dx.doi.org/10.21511/dm.17(2).2019.04 \\
\hline RELEASED ON & Thursday, 15 August 2019 \\
\hline RECEIVED ON & Thursday, 16 May 2019 \\
\hline \multirow[t]{2}{*}{ ACCEPTED ON } & Wednesday, 19 June 2019 \\
\hline & \begin{tabular}{|l|l|}
$(c))_{\text {EY }}$ \\
\end{tabular} \\
\hline LICENSE & $\begin{array}{l}\text { This work is licensed under a Creative Commons Attribution } 4.0 \text { International } \\
\text { License }\end{array}$ \\
\hline JOURNAL & "Development Management" \\
\hline ISSN PRINT & $2413-9610$ \\
\hline ISSN ONLINE & $2663-2365$ \\
\hline PUBLISHER & LLC "Consulting Publishing Company "Business Perspectives" \\
\hline FOUNDER & Simon Kuznets Kharkiv National University of Economics \\
\hline & 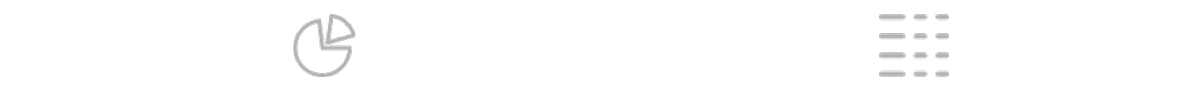 \\
\hline NUMBER OF REFERENCES & NUMBER OF FIGURES \\
\hline
\end{tabular}

(C) The author(s) 2022. This publication is an open access article. 


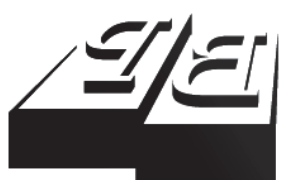

BUSINESS PERSPECTIVES

Publisher

LLC "CPC "Business Perspectives" Hryhorii Skovoroda lane, 10, Sumy, 40022, Ukraine www.businessperspectives.org

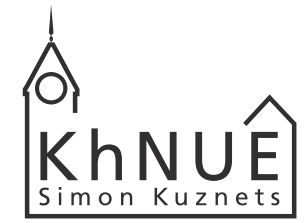

\section{S. KUZNETS KHNUE}

\section{Founder}

Simon Kuznets Kharkiv National University of Economics, Nauky avenue, 9-A, Kharkiv, 61166,

Ukraine

http://www.hneu.edu.ua/

Received on: 16th of May, 2019

Accepted on: 19th of June, 2019

\section{(C) David Schultz, 2019}

David Schultz, Professor, Department of Political Science, Hamline University, USA

\section{(c) (i)}

This is an Open Access article, distributed under the terms of the Creative Commons Attribution 4.0 International license, which permits unrestricted re-use, distribution, and reproduction in any medium, provided the original work is properly cited.

\title{
REFLECTIONS ON THE PROSPECTS FOR DEMOCRACY IN AFRICA AND ON THE IMPEDIMENTS TO THAT HAPPENING
}

\begin{abstract}
Approximately a half-century after the end of colonialism few countries in Africa have established long-term stable democracies. Instead, the last 50 years have witnessed either repeated failures or even regression or departure from the path to democracy. This article seeks to examine why. It discusses the current continent-wide state of and prospects for democracy in Africa in light of leading theories on democratic development. Part one of the article examines the western concept of democracy for the purposes of definition and suitability for Africa. It then describes both the values and requisites for a democracy to exist, including the socio-economic and institutional structures required. The article then draws upon a unique database constructed here that examines the relationship between democracy, economic development, poverty, and GDP, among other cross-national aggregate data. The article concludes with what ta discussion of what factors seems to be missing to entrench democracy across Africa, and observations regarding the impediments remaining to forming democratic regimes on this continent.
\end{abstract}

\section{Keywords}

JEL Classification

Девід Шульц (США)

\section{РОЗДУМИ ПРО ПЕРСПЕКТИВИ РОЗВИТКУ ДЕМОКРАТІЇ В АФРИЦІ ТА ПЕРЕШКОДИ НА ІЇ ШЛЯХУ}

\begin{abstract}
Анотація
Приблизно через півстоліття 3 часу ліквідації колоніалізму в декількох африканських країнах було створено довгострокові стабільні демократичні відносини. Натомість протягом останніх 50 років мали місце або постійні невдачі, чи навіть регрес, або відхід від шляху до демократії. Мета даної статті - з'ясування причин. Обговорюється сучасний стан континенту та перспективи демократії в Африці у світлі провідних теорій демократичного розвитку. Досліджується західна концепція демократії з метою визначення ії̈ придатності для Африки. Описано цінності та передумови для існування демократії, зокрема необхідні соціальноекономічні та інституційні структури. Використано унікальну базу даних, що сприяє вивченню взаємозв'язку між демократією, економічним розвитком, бідністю та ВВП, серед інших міждержавних сукупних даних. Обговорюється те, яких факторів не вистачає для захисту демократії в Африці, та які перешкоди ще залишаються на шляху до ії створення на континенті.
\end{abstract}

Ключові слова

Класифікація JEL
Африка, демократія, модернізація, демократизація

H10, P47

\section{INTRODUCTION}

More than a half-century after the end of colonialism, democracy in Africa is still an enigma. By all counts and international measures African states generally rate poorly when it comes to respect for human rights, election integrity, corruption, and fair and impartial public administration. 
While 50 years ago independence looked to have situated much of Africa within what Samuel Huntington called second wave democratization (1991), the ability to stabilize western European style democracy across the continent not only appears to have had mixed success, but organizations such as Freedom House even describe a retreat from it (2010). Additionally, others contend that democracy or one manifestation of it - elections - are merely a facade or shell that mask underlying anti-democratic or authoritarian regimes (Adebanwi, \& Obadare, 2012). The question is why? Why specifically after 50 years has democracy faced such a rough road and what are the future prospects for democracy forming and flourishing across Africa? This is the subject of this article. ${ }^{1}$

This article generally will ask the question why democracy across the 54 countries of Africa has been so difficult to establish and maintain. To answer this question, the article does several things. First, it seeks to define what a democracy is and to ask if the concept, rooted in Europe, suitably applies to Africa. Second, the aticle examines the empirical research regarding what conditions are required or are preconditions for democracy. Third, drawing upon a unique database constructed for this article, it examines cross-national aggregate variables that are seen as linked to democracy based on previous empirical research. The goal here is to determine what factors are present or absent in terms of assessing the development and future prospects for democracy across the African continent. The conclusion then generalizes to an assessment on the state of democracy in Africa, suggesting also future research questions.

\section{LITERATURE REVIEW}

\subsection{What is a democracy?}

Forging democracies is not easy. Nor is the concept a fixed term. As former United States Supreme Court Justice Thurgood Marshall once remarked about America: "When contemporary Americans cite "The Constitution" they invoke a concept that is vastly different from what the Framers barely began to construct two centuries ago" (Marshall, 1987). "We the people," the opening words of the US Constitution, hardly included more than white propertied males when the Framers drafted this document in 1787. Marshall's point was that creating democracies is not something that happens at once, but it is often a long product of struggle and experiment to build the institutions and values that today one would represent what a democratic state is.

Western European and North American style democracies are indebted to a confluence of three political traditions that inform the way their institutions operate. These traditions are democracy, liberalism, and constitutionalism.

The concept "democracy" is very old, dating back to Plato and the ancient Greeks who saw it as a rule by the masses (Pennock, 1979). More modern notions of democracy labeled it a form of popular government where the people rule, either directly, or indirectly, through their representatives, based upon the principle of majority rule. Huntington declares the essence of democracy as one where representatives are chosen by the people in fair, honest, and competitive elections (1991, p. 7).

"Liberalism," a concept whose origins is often traced to John Locke, represents a set of political values committed to the protection of individual rights, polities instituted on the basis of the consent of the governed, and to a notion of a limited government (Pennock, \& Chapman, 1983; De Ruggiero, 1959). Third, "constitutionalism" as a concept is also very old, again dating back to the ancient Greeks (Mcllwain, 1958; Pennock, \& Chapman, 1979), especially Aristotle, and it refers to the basic structures, "Grundnorm", or rules that constitute a government.

As the term has evolved in Western Europe and North America, constitutionalism refers to a government of limited powers, one which often must adhere to rule of law, procedural due process or regularity, and a commitment to the protection of individual rights (McHugh, 2002). However, as both Fuller (1975) and Dyzenhaus (2006) argue, adherence to rule of law is more than a formal set of rules. For Fuller, there are eight requisites to giving the law an inner morality that constrains arbitrary actions (Fuller, 1975, pp. 33-38) Similarly, Dyzenhaus asserts that the

1 The original paper was presented at the Africa-Israel Policy and Leadership Conference, March 7-9, 2016, The Truman Institute, Hebrew University of Jerusalem, Jerusalem, Israel. I write this article less as an expert on Africa and more a student of democracy with the intent to stimulate discussion about the prospects for democracy across all of Africa and less in terms of providing answers about specific countries. 
inner morality of law as described by Fuller is more than a procedural adherence to rule of law. Instead, rule of law imposes a substantive limit on the government. Hence, he rejects the idea that there needs to be special constitutional rules or powers during emergencies (pp. 59-72).

Together, democratic, liberal, and constitutional values are important in the United States, England, and many if not all of the European Union (EU) member states (Macpherson, 1973). Even if the exact application of the three values varies across these countries, commitments to majority rule balanced by minority rights, procedural regularity, and a government subject to some limits, are shared by many countries in the west claiming to be democracies (Powell, 2000).

Thus democracies have their own unique values structure. According to Schultz:

"Democratic theories have ontologies. Each defines its object of inquiry, the critical components of what makes a political system work, and what forces, structures, and assumptions are core to its conception of governance. This ontology will not only include a discussion of human nature but also examination of concepts such as representation, consent, political parties, liberty, equality, and a host of other ideas and institutions that define what a democracy is and how it is supposed to operate" (Schultz, 2002, p. 74).

The ontology of a democracy is what distinguishes it from other types of political regimes. According to Dahl, polyarchies - the term he prefers to use in lieu of democracy - are too characterized by a distinct set of values (Dahl, 1956, 1971). What are they?

\subsection{Democratic Values}

Dahl lists five of what he calls criteria or values for a democracy (Dahl, 1989, p. 222). These five are voting equality, effective participation, enlightened understanding, control of the agenda, and inclusion. Dahl's criteria are similar to what other democratic theorists have described as the requisites or values central to describing what a democracy is (Pennock, 1979; Sartori, 1987).

If democracy means anything it seems to include idea of some sort of equality (Pennock, 1979, p. 35; Sartori, 1987, pp. 58-59, 342-344). Now there are significant debates regarding what type of equality is demanded of a democratic society. Dahl himself argues for both a procedural or formal sense of equality before the law as well as sometime of substantive equality in terms of economic resources (Dahl, 1989). Others too have described various meanings of equality as essential to democracy (Locke, 1996; Rousseau, 1977; Mill, 1986; Dworkin, 1978). Theorists such as Rawls have rendered similar claims, contending that a liberal democracy adhering to his two principles of justice - equal liberty for all consistent with like liberty for others, and the structuring of economic inequalities so that they are of benefit to the least advantaged representative person in society - demand something approaching an equality both in terms of economic conditions and equality before the law.

For Dahl, the concept of equality includes the important notion of individual moral autonomy (Dahl, 1989, pp. 97). For many theorists, democracy begins with the idea of individuals liberty or freedom. For Locke, the idea that government derives its justification from a social contract and consent of the people is a powerful metaphor to enabling a theory about limited government. The government derives its just ends (as it states in the American Declaration of Independence) from the people. Other theorists, such as Jean-Jacques Rousseau and Immanuel Kant, echo similar thoughts. For Rousseau the concept of freedom resides in conforming to the general will is an important one. It is here where the people get to make the laws that will govern them that one gets a sense of Rousseauian democracy. For Kant, the very notion of autonomy - living according to rules that one has legislated for herself - is the purist notion of what a democracy is (Kant, 1978; Rawls, 1973, p. 252-254). It is self-rule. It is where the people, as French political theorist Jean Bodin stated, are sovereign (Bodin, 2003). Democracies are where the people hold political power, either directly or indirectly, and generally, at least in the United States, are viewed as the ultimate source of authority. 


\subsection{Requisites of a democracy}

After World War II a major concern of American and European political scientists was democratic stability. Two questions dominated the discipline: First, why or how did Fascism and Nazism develop out of ostensibly democratic states and, second, what could be done to stabilize democracies so that they would not degenerate into either authoritarian or communist states. In short, the political science literature of the 1950s and 1960s was perplexed by the question of how to maintain liberal democracies (Ceaser, 1993, p. 41, 46).

Numerous studies sought to locate those institutions and values necessary to maintain stable democracies (Lijphart, 1968; Neubauer, 1967). Factors found important included economic wealth and modernization (Lipset, 1960, p. 28, 87, 116; Dahl, 1971, pp. 60-62; Huntington, 1984, p. 193, 199; Lipset, 1959; Lipset, 1960; Needler, 1968; Rustow, 1968; Rostow, 1971); political participation (Lipset, 1960, p. 116); civilian control of the government (Diamond, 1989, p. 344; Huntington, 1956), and widely-supported and regularized political mechanisms to resolve conflict (Almond, \& Verba, 1963, p. 363; Dahl, 1976, p. 364; Huntington, 1984). They stressed the importance of a democratic political culture that inculcated toleration and a reasonable balance of both social consensus and cleavage, including a respect for difference and a commitment to resolve these differences through the political process (Almond, \& Verba, 1963, p. 363; Lipset 1960, p. 1, 4, 78, 250; Dahl, 1971, p. 105; 1960, p. 347; Christoph, 1965). Equally important though, democracy required a social pluralism with crosscutting loyalties, expressed through multiple, competing groups (Lipset, 1960, p. 78). The significance of overlapping loyalties among social cleavages was to prevent the emergence of social alignments polarizing a nation along race, ethnicity, religion, or other traditional lines of conflict and division. This social pluralism is also central to two other concepts in democratic theory, social capital and civil society.

In Making Democracy Work (Putnam, 1993) the focus was on explaining institutional performance by way of an examination of the northern and southern Italian regions. In noting that the wealthier, more modern regions of the North have a head start over their poorer counterparts in material and human resources, Putnam ties economic performance to the performance of public and civic institutions (p. 85). Speculating on the causes of the strength of these civic institutions he identifies active citizen engagement and participation in public affairs as important (p. 87), along with political equality (p. 88), and solidarity, trust, and tolerance (p. 89). These norms, according to Putnam, are "embodied in, and reinforced by, distinctive social structure and practices," and the most important of these institutions are civil associations (p. 89). Borrowing from Tocqueville, Putnam argues that these associations instill internally in their members a sense of cooperation, trust, public-spiritedness, a tempering of self-interest, and other important values critical to democratic practice (pp. 89-90). Externally, these groups have a wider impact upon the polity, producing moderation of group conduct and cross-pressures (p. 90). ${ }^{1}$

The performance of representative government is facilitated by the social infrastructure of civic communities and by the democratic values of both officials and citizens. Most fundamental to the civic community is the social ability to collaborate for shared interests. Where norms and networks of civic engagement are lacking, the outlook for collective action appears bleak. Generalized reciprocity thus generates high social capital and underpins collaboration. This type of harmony in society illustrates how voluntary collaboration can create value that no individual regardless of income and intelligence could produce alone (p. 183). In the civic community, associations proliferate, memberships overlap, and participation spills into multiple arenas of community life. Overall, the performance of democratic institutions is enhanced by a developed civil society (p. 182).

Critical to Putnam's equation is how involvement in voluntary associations generates social capital. Quoting from James Coleman conception of the term, Putnam here defines social capital as those "features of social organization, such as trust, norms, and networks, that can improve the efficiency of society by facilitating coordinated actions" (Putnam, 1993, p. 167). In drawing upon this definition of social capital and the way it is employed in Making Democracy Work, social capital has more of a, well, social aspect to it. Social capital is not the individual property of any individual. Instead, it is the connective tissue, shared norms, and community values that undergird social cooperation and intercourse. Social capital is not divisible; instead it is a structural byproduct of engagement in and through voluntary associations (Tarrow, 1996). Moreover, voluntary associations are part of an embedded social structure, one part of several institutions necessary to making democracies work. 
Hence, the postwar political science paradigm argued that the trick to maintaining democratic stability rested in part on the encouragement of secular national values which all groups supported (Lipset, 1960, p. 68), the maintenance of overlapping loyalties, and the replacement or amelioration of the divisive forces of race, ethnicity, and religion with less divisive interest politics that could be politically compromised through the electoral and political process (Rabushka, \& Shepsle, 1972; Lijphart, 1968; Lijphart, 1977, p. 19; Kornhauser, 1959; Easton 1965; Huntington, 1968; Budge, 1970; Pennock, 1979, pp. 206-259). These empirical studies stated that democracies depend on support for broad social and political toleration of diverse groups and dissident views as well as a set of regularized and peaceful mechanisms to reconcile disputes without censorship or force. These studies also emphasized that attainment of a certain level of economic conditions or affluence was required, or that a strong middle class was required, or that the gaps between the rich and the poor could not be too great such that there was unchecked class conflict or antagonisms.

Overall, democracy is more than mere form or procedures. By that, there are procedural and political institutional aspects that seem important to defining what a democracy is. But democracies also require some substantive components, including an inner morality of law, respect for rule of law, a political culture, social capital, and a set of civil and economic institutions.

\section{METHODS}

So given the above requisites, how do the countries of Africa measure up as democracies? First, one can contest a Eurocentric notion of democracy. By that, the main concepts regarding what constitutes a democracy are grounded in European and North American conceptions of the term. Some scholars have argued for a plural conception of the term, suggesting that there may be a unique African conception (Adebanwi, \& Obadare, 2012, pp. 40-41). Thus, one should not use Eurocentric definitions and measures of democracy since they express a bias or preference for a type of democracy perhaps not suitable or appropriate for Africa. This is a legitimate criticism.

Conversely, such as argument also implicitly seems to suggest that the countries of Africa are incapable of achieving the same measure of democracy when compared to other parts of the world, or that the countries of this continent need to develop their own conception of democracy. Such claims suggest that the best one an ever hope for is something approaching second rate or inferior democracies, and that African states will never be able to live up to the international democratic standards, or at least those found in Europe and North America. Thus we should hold Africa to a lower democratic standard since the countries of the continent are incapable or achieving real democracy. Such a claim is derogatory and condescending. There is no reason to say or expect that the countries of Africa cannot be democratic. Granted not all democracies need be modeled on say the United States, or be fundamentally be market economies, but nonetheless, as noted above, democracies do have some core notions expressed in terms of respect for individual rights, freedom, honest competitive elections with real changes in power, and the ability of voters to select and control their leaders.

How do African countries measure up? Many of the major international tests draw upon the definitions and requisites of democracy as described above.

Freedom House has ranked nations of the world since 1973 (2015). It uses three composite rankings. The first looks at political rights and the second civil rights. Counties are scaled on a score of 1-7, with 1 representing the highest level of freedom, 7 the lowest. Freedom House also categorizes countries along three dimensions: free, partially free, and not free. States whose ratings average 1.0 to 2.5 are considered Free, 3.0 to 5.0 Partly Free, and 5.5 to 7.0 Not Free. This research combined Freedom House's rankings with those of several other organizations to measure the performance of democracy in Africa. The Freedom House rankings were combined with a data set that included Transparency International's ranking on corruption and data on economic development and GDP from the World Bank. This information was then analyzed to ascertain any correlations among democratic standing, corruption, and economic development, inequality, and poverty. 


\section{RESULTS}

\subsection{The State of Democracy in Africa}

One can compare scores from the 1973 and 2016 rankings. In 1973 (based on 1972 data) the median score for an African state on political rights in 1973 was 5.875, in 2016 (based on 2015 data) it was 4.50. This means in 1973 the 5.875 score ranked African states as generally unfree when it comes to political rights, and partially free in 2016. Using a two-tail $T$ test, the $t$-value is 3.68101 . The $p$-value is .000194 . The result is significant at $p<.05$. This means that on average there has been an improvement in respect for political liberties across Africa from 1973 to 2016.

Second, in 1973 the median ranking for civil liberties was 5.125, while in 2016 it was 4.32. Again running a twotail $T$ test the $t$-value is 3.18033. The $p$-value is .001993. The result is significant at $p<.05$. In general an improvement but African states generally remained in the unfree category during these time periods. In the 1973 report Freedom House ranked only two states - Gambia and Mauritius - as free, in the 2015 report ten states - Benin, Botswana, Cape Verde, Ghana, Mauritius, Namibia, Sao Tome \& Principe, Senegal, South Africa, and Tunisia are classified as free. Overall, in 197332 states are listed as unfree, in 2016 the number was 22. Democracy has generally improved compared to 1973, but certainly one cannot say that democracy is sweeping the continent. Additionally, comparing 1973 to 2016 misses something crucial -progress made and then regression. As Freedom House points out, democratic gains were made across much of Africa in the 1970s and into the 1980s, only to see overall and specific countries eventually regress or retreat from democracy (Freedom House, 2010).

\subsection{Corruption in Africa}

Perhaps another measure or ranking is to look to Transparency International's corruption index (2015). Corruption is measured on a scale of 0-100, with the higher the score the least corrupt. Using the most recent data from 2014, the median score for all countries ranked in the world was 43.18, for Africa it was 33. Statistically, using a two-tail T-test, the $\mathrm{t}$-value is -3.60972 . The $p$-value is .000377 . The result is significant at $p<.05$. If one compares Africa to all other non-African states, the comparison is 33 to 47.68 . Here the $t$-value is 4.84552 . The $p$-value is $<.00001$. The result is significant at $p<.05$. One can conclude that African states are more corrupt than the world average, and the average for all non-African countries. Individually, Botswanna, with a composite score of 63, was the highest ranked African county, coming in at $31^{\text {st }}$ in terms of least corrupt.

As noted above, colonial independence in Africa was part of what Huntington called the second wave of democratization worldwide (1991). Securing independence was a critical step toward forming a democracy. Yet studies by Freedom House, for example (2010) point to backsliding by many African countries, having moved toward democracy they retreated. Or they developed forms of democracy while really not being democratic. For example, across Africa elections were used to legitimize autocratic or anti-democratic rules. Serious opposition was lacking, or there was widespread election corruption or questions about voting integrity. Or many of the states were described as hybrid democracies containing many features or institutions inconsistent with democracy, such as presidencies with strong men who effectively lacked any horizontal checks on their power even though they appeared to be elected into office (Van Cranenburgh, 2012, p. 177).

\subsection{Political Stability in Africa}

By one estimate between the years of independence and 2012 there have been at least 200 failed and successful military coups in Africa (Barka, \& Ncube, 2012). Alone between 1990 and 2001 there were 50 attempted military coups in sub-Saharan Africa (p. 3). During the 1960s and 70s "nearly three-quarters of the African leaders who left power... did so through a coup, violent overthrow, or assassination" (Posner, \& Young, 2010, p. 62). By the 1990s, peaceful transitions of power were more regularized. Yet peaceful civilian transfer of power through elections are described as the exception and not the rule across the continent. Additionally, after a burst of activity during the Arab spring, perhaps only Tunisia has moved closer to democracy. Egypt and Libya have either made no net progress or regressed. However, there is some evidence that subsequent to some military intervention it produced regime liberalization and that such action and military rules are increasingly seen as illegitimate by many African 
citizens (Clark, 2010). Many political elites, including in the AU, also seem to be rejecting coups and preferring multi-party elections (Crawford, \& Lynch, 2012, p. 23). States with histories of repeated fair and free elections seem to be developing supporting for human freedom and democratic values (Crawford, \& Lynch, 2012, p. 5) and lessoning their support for military coups (Clark, 2010, p. 85).

\section{DISCUSSION}

\subsection{Economic Development and Democracy}

So why have African states generally been slow in developing stable democracies? This question is about the process of democratization. If parts one and two of this article discussed what constitutes a democracy and what its requisites are, here the focus is on the process of states building democracies. There are several possible theories regarding the requisites for democracy building.

One of the classic theories is modernization (Lim, 2010, p. 184). The general modernization thesis is that there is a connection between economic development and democracy. Seymour Lipset saw democratization as the final product of economic development. This is the case because, according to Przeworski and Limongi (1997, p. 156157) modernization creates a "differentation and specialization of political structures from other structures and make democracy possible". Modernization or economic develop creates conditions that make democracy possible, such as the emergence of civil societies, but it does not necessarily guarantee democracy will occur (Lim, 2010, p. 185). Democracy cannot exist without economic modernization, but the latter does not guarantee the former. Significant economic development, such as in China, Singapore, or the contemporary Russian Federation are proof of this.

A variation of modernization or economic development theory is the assertion that political democracy and capitalism are related. More specifically, the assertion is that there is a historic relationship between the rise of capitalism and democracy, with market and political freedoms mutually reenforcing one another (Lim, 2010, p. 186).

A third variation is not so much is democracy a product of economic development or capitalism per se, but that instead democracies require a degree of social and economic equality to develop (Lim, 2010, p. 186; Rueschemeyer, Stephens, \& Stephens, 1992, p. 41). Capitalist development or modernization that improves the economic conditions will foster democracy if it strengthens working and middle class power in relation to that of the political elites. Development empowers some classes, thereby giving them the ability to wrestle power away from the ruling elite.

\subsection{Democracy and Inequality}

One standard measure of inequality is the GINI coefficient. This measure is on a scale from zero to 100, with zero representing no economic inequality between the rich and poor, while 100 would represent perfect inequality. Many organizations compute GINI, but for this article the most recent, December 16, 2015 calculations from the World Bank shall be used. The World Bank data has reference points for most countries, including those in Africa, ranging from the late 1990s through 2013. Using this data, one finds a world GINI average of 35.2. For Africa the average is 43.39. Clearly African countries have a greater degree of economic inequality than the rest of the world. On the face this might explain the difficult road to democracy in Africa. Yet a 43 GI NI does not necessarily mean that a democracy is impossible. Among major countries of the world with GINI's approximately this one finds the United States at 41.1. Granted the US has the largest GINI of all democracies and it is still smaller than the African average, but nonetheless the African mean may or may not be beyond the boundary of what is necessary for a democracy, even if individual states in Africa may exceed even this mean.

Perhaps there is some correlation between GINI correlation and a Freedom House classification. By that, is there any correlation between a country label and how economically equal the population is? Running a correlation of countries where both GINI numbers and Freedom House classification are found, the correlation is 0.018. 
Essentially no correlation between democracies and degrees of economic equality. But if instead a correlation is run between per capita GDP and Freedom House classification as free, the correlation is 0.439 - a low to modest but definite relationship.

There is some connection between democracies and levels of economic modernization or development. For example, among those states Freedom House classifies as free, partially free, and not free, the mean GDP per capita is 14.476 USD, 3.682 USD, and 4.830 USD. There is not a significant difference between the incomes of the not free and partial free but the gap between them and free is significant. In comparison the median GDP per capita for African states is 8.034 USD - far less than that for free countries. This lends additional support to the claim that income or poverty (development) is a factor impacting the prospects for African democracy. However, as Lewis points out (2010), there is a significant disconnect between democracy and development across Africa with some of the poorest countries sustaining democracy while economic growth has not been accompanied by rise in incomes or the fostering of democratic institutions, in part because of political corruption. African countries may thus be caught in a vicious circle: economic development may be necessary for further democratization, yet the former is limited by the absence of stable democratic structures (Diamond, 2010, p. 56). Democratization and development are related but it is unclear regarding the lines of causality between the two.

\subsection{Top-Down or Bottom-Up Democracy}

A second group of theories emphasizes the development of democracy either from above or below. In arguing that democracy arises from above, O'Donnell and Schmitter (1986) see democracy as a byproduct of elite conflict. When elites divide among themselves it develops incentives for them to support democracy. It does so either as ways for each to maintain power checks upon one another, or to appeal to masses for political support. Critical here are the nature of the types of authoritarian regimes. Huntington saw the attitude of political elites as critical in promoting the transition toward democracy across the world during the third wave in the 1980s (1991, p. 124). Geddes (1999) argues that there are four types of authoritarian regimes - personalist, military, single-party, and an amalgam of the first three. Military regimes are more likely to transition to democracy because of potential splits in army elites, whereas single-party are the most stable and least likely to transition. Their stability is a result of mass support of elites who are linked through a single party. Given that most regimes in Africa are personalist, single-party, or a hybrid, regime type seems not to lay the foundation for the best chance to democratization.

Conversely, theories declaring that democracy comes from below see it origins in demands among workers initially through mass protests or mobilization. Elites, seeking to preserve their positions, effectively compromise with the masses, resulting in the development of constitutional or democratic structures to limit their authority. Additionally, development of democracy from the bottom up means a fostering of democratic attitudes and support among citizens and this gets to a third a third theory regarding democratic transitions addresses culture.

Huntington (1991) asserted that some cultures across the world simply are not compatible with democracy. This claim is an update of Almond and Verba's argument in Civic Culture (1963). Cultures either foster impediments to attitudes and values necessary for democracies to form or they can provide support-such as commitment to toleration, rule of law, or peaceful resolution of conflict. Culture arguments assert that cultures are fixed and therefore some states will never be democracies, or need to assert that some forces, such as modernization, can force changes in cultural attitudes, either among elites, the masses or both. In the former one can argue that either the political cultures of many African states are not compatible with democracy (a circular or question begging argument) or that outside forces such as economic modernization have not developed fully to develop sufficient political support for democracy.

Polling data on public opinion in specific countries would thus be appropriate way to assess the democratic culture argument. However, Diamond (2010, pp. 52-53) contends that there are some signs of the emergence of civil societies along the lines Putnam would describe, indicating growing support for democracy. More than 60\% surveyed by Afrobarometer support democracy (Diamond, 2010, XVI). Yet despite this support, Diamond also reports that the institutional support for democracy, as measured by World Bank indices that including rule of law and effective public administration of services, are lagging in Africa (p. 54). 


\section{CONCLUSIONS}

Recent electoral contests in the Central African Republic (Benn, 2016) and Uganda (Gettleman, 2016; Kron, 2016) demonstrate that despite elections, challenges remain for the development of more than a formal democracy. So what are some of the reasons for the failure of democracy to firmly root across Africa? This article, based upon a cross-national aggregate analysis, has identified several factors critical to the establishment of democracy across this continent.

First, nations fail often because of bad institutional design and feed off of poverty and create a vicious circle (Acemoglu, \& Robinson, 2012). Specifically, the formal institutions and structures of democracy do matter. There must be both horizontal and vertical checks and balances or limits on power, especially on executives. Missing across much of Africa are fully developed structures to limit power, especially upon presidents. Additionally, while elections do take place across the continent, they are more contests in form than substance. They are marred by corruption or fraud, often they are not really competitive, with meaningful opposition. Instead, they are more facades to mask authoritarian power. However, these elections are held to please western governments or funders who insist on them as prerequisites for funding (Adebenwi, \& Obadare, 2012). Despite the apparent facade these elections may seem, they are an important process in democratization, yet they need to be transformed into competitive multiparty contested events where there are serious prospects for stable changes in control of the government. It is not clear based on recent elections across Africa how likely that will be in the foreseeable future.

But perhaps the biggest issues challenging the prospects for democracy in Africa are the one identified in this article, specifically economic, cultural, and leadership. In terms of economics this article found it is less the gap between the rich and poor and more the relative poverty of countries in Africa that is possible impediment to democracy. Democracies across the world seem to tolerate some economic inequality, although across Africa its countries push the far limits of what may be possible in terms of a rich-poor gap to sustain democracy. Instead, compared to other free countries of the world, African countries are generally poorer. Thus, there is some evidence that the lack of economic development or modernization is in part a problem impeding democracy (Huntington, 1991, p. 315). This article confirmed this claim.

Modernization brings with it changed cultural attitudes toward democracy. It empowers some groups, creates demands for more freedom. Moreover, the practice of democracy reinforces democracy. By that, the lack of successful democratic elections with peaceful transitions, or otherwise the lack of experience with democratic governance in specific countries and across the continent means that there is not a cultural or institutional memory or support built for democracy. Democracy may be a habit of the heart and without a habit of successful democracy it cannot sustain itself. In effect, there is a feedback loop to democratic practice that is missing. While there is evidence that there is growing public support for democracy across Africa, here too the depth of that support along with a commitment to democratic practices and institutions found in Europe and North America may be lacking (Bratton, 2010). Again, analysis of the history of stable elections and transitions of power across Africa suggest that what has yet to emerge across the continent is a democratic political culture that endorses this form of government. In other words, there seems to be significant toleration for non-democratic uses of power and corrupt practices that inhibit democracy.

Finally, there is the issue of elite support for democracy. Unlike in the third wave of democratization that swept Europe following the fall of the Berlin Wall where political elites supported democracy, this is often missing in the countries across Africa as evidenced by formal political coups, delayed elections, or refusal of elites to leave office when terms expire. The commitment of rulers to rule of law, to supporting free and fair elections, civilian rule, and peaceful transitions are missing. Lacking elite support, especially when they are united, creates little opportunity for opposition parties to emerge, or for an independent civil society to flourish. Combine this lack of elite support along with the intense corruption that pervades many countries that prevents state or national resources from being invested in economic development, and the results, not surprisingly, do not lay the groundwork for the emergence or prospects for stable democracies to form or flourish. 
Overall, this article found significant barriers to democracy across Africa in terms of an absence of the require economic, cultural, and elite support. These are significant impediments to democracy and do not bode well for the future of political freedom and free institutions across Africa. Future research should examine more specifically several questions. One, as noted, democracy and some level of economic development are connected. This article has not identified the line of causality. By that, do democratic institutions encourage economic development or vice versa. Understanding more clearly this relationship might provide important answers about possible reforms necessary to encourage democratic reform. Two, this article did not look at specific reform strategies, such as how campaigns against corruption, international economic investments, international election monitoring, or constitutional revisions might impact democracy's prospects across Africa. Finally, the article did not seek to settle the question whether the concept of democracy in its European form is an appropriate or suitable form of government for all or part of Africa.

\section{REFERENCES}

1. Acemoglu, D., \& Robinson, J. A. (2012). Why nations fail: the origins of power, prosperity, and poverty (546 p.). New York: Crown Business.

2. Adebanwi, W., \& Obadare, E. (2012). The abrogation of the electorate: an emergent African phenomenon. In Crawford, G., \& Lynch, G. (Ed.). Democratization in Africa: challenges and prospects (pp. 37-61). New York: Routledge.

3. Almond, G. A., \& Verba, S. (1963). The civic culture. Boston: Little Brown.

4. Barka, H. B., \& Ncube, M. (2012). Economic brief-political fragility in Africa: are military coups d'etat a never-ending phenomenon? African development bank group. Retrieved from https://www.afdb.org/en/documents/document/economic-brief-political-fragilityin-africa-are-military-coups-detat-a-never-ending-phenomenon-29430

5. Benn, M. (2016). Newly elected Central African Republic leader faces hard realities. New York Times (February 22), A7. Retrieved from https://www.nytimes.com/2016/02/22/world/africa/newly-elected-central-african-republic-leader-faces-hard-realities.html

6. Bodin, J., \& Franklin, J. (Ed.) (2003). On sovereignty: four chapters from the six books of the commonwealth (Cambridge texts in the history of political thought). New York: Cambridge University Press.

7. Bratton, M. (2010). Formal versus Informal Institutions in Africa. In Diamond, L., \& Plattner, M. F. Democratization in Africa: progress and retreat (pp. 103-120). Baltimore: Johns Hopkins University Press.

8. Budge, I. (1970). Agreement and the Stability of Democracy. Chicago: Markham Publishing Co.

9. Ceaser, J. W. (1993). Reconstructing political science. In Elkin, S. L., \& Soltan, K. E. A new constitutionalism: designing political institutions for a good society. Chicago: University of Chicago Press.

10. Cheeseman, N. (2012). The internal politics of power-sharing in Africa. In Crawford, G., \& Lynch, G. Democratization in Africa: challenges and prospects (pp. 62-91). New York: Routledge.

11. Christoph, J. B. (1965). Consensus and cleavage in British political ideology. American political science review, 59, 629-642.

12. Clark, J. F. (2010). The decline of the African military coup. In Diamond, L., \& Plattner, M. F. Democratization in Africa: progress and retreat (pp. 73-87). Baltimore: Johns Hopkins University Press.

13. Crawford, G., \& Lynch, G. (2012). Democratization in Africa 1990-2010: an assessment. In Crawford, G., \& Lynch, G. Democratization in Africa: challenges and prospects (pp. 1-36). New York: Routledge.

14. Crawford, G., \& Lynch, G. (2012). Democratization in Africa: challenges and prospects. New York: Routledge.

15. Dahl, R. A. (1956). A preface to democracy theory. Chicago: University of Chicago Press.

16. Dahl, R. A. (1971). Polyarchy: participation and opposition. New Haven: Yale University Press.

17. Dahl, R. A. (1976). Democracy in the United States: promise and performance. New Haven: Yale University Press.

18. Dahl, R. A. (1979). Who governs? Democracy and power in an America $n$ city. New Haven: Yale University Press.

19. Dahl, R. A. (1989). Democracy and its critics. New Haven: Yale University Press.

20. De Ruggiero, G. (1959). The history of European liberalism. Boston: Beacon Press.

21. Diamond, L. (2010). Introduction. In Diamond, L., \& Plattner, M. F. Democratization in Africa: progress and retreat (pp. IX-XXVIII). Baltimore: Johns Hopkins University Press.

22. Diamond, L. (2010). The rule of law versus the big man. In Diamond, L., \& Plattner, M. F. Democratization in Africa: progress and retreat (pp. 47-58). Baltimore: Johns Hopkins University Press.

23. Diamond, L. et al. (Eds.) (1989). Democracy in developing countries: Latin America. Colorado: Lynn Reinner.

24. Dworkin, R. (1978). Taking rights seriously. Cambridge: Harvard University Press.

25. Dyzenhaus, D. (2006). The constitution of law: legality in a time of emergency. New York: Cambridge University Press.

26. Easton, D. (1965). A framework for political analysis. New Jersey: Prentice-Hall.

27. Freedom House (2010). Freedom in the world 2010: erosion of freedom intensifies. Washington: Freedom House.

28. Freedom House (2015). Freedom in the world 2015. Retrieved from https://freedomhouse.org/report/freedom-world/ freedom-world-2015\#.Vs4_R_krLrc

29. Fuller, L. (1975). The morality of law. New Haven: Yale University Press.

30. Geddes, B. (1999). What do we know about democratization after twenty years? Annual review of political science, 2, 115-144.

31. Gettleman, J. (2016). Uganda moves toward "Democracy light" amid elections. New York Times (February 18), A9.

32. Huntington, S. P. (1956). Civilian control and the constitution. American political science review, 50, 676-699.

33. Huntington, S. P. (1968). Political order in changing societies. New Haven: Yale University Press.

34. Huntington, S. P. (1984). Will more countries become democratic? Political science review, 99, 193-199. 
35. Huntington, S. P. (1991). The third wave: democratization in the late twentieth century. Norman: University of Oklahoma Press.

36. Kant, I. (1978). Foundation of the metaphysics of morals (text and critical essays edited by Wolff, R. P.). Indianapolis: Bobbs-Merrill.

37. Kornhauser, W. (1959). The politics of mass society. Illinois: The Free Press.

38. Kron, J. (2016). Irregularities and delays amid voting in Uganda. New York Times (February 19), A10.

39. Lewis, P. (2010). Growth without prosperity in Africa. In Diamond, L., \& Plattner, M. F. Democratization in Africa: progress and retreat (pp. 88-102). Baltimore: Johns Hopkins University Press.

40. Lijphart, A. (1977). Democracy in plural societies. New Haven: Yale University Press.

41. Lijphart, A. (1968). Typologies of democratic systems. Comparative political studies, 1, 3-35.

42. Lim, T. C. (2010). Doing comparative politics: an introduction to approaches and issues. Boulder: Lynne Rienner Publishers.

43. Lipset, S. M. (1959). Some social requisites of democracy: economic development and political legitimacy. American political science review, 53, 69-105.

44. Lipset, S. M. (1960). Political man: the social bases of politics. New York: Anchor Books.

45. Locke, J. (1996). Two treatises of government. New York: Cambridge University Press.

46. Macpherson, C. B. (1973). Democratic theory: essays in retrieval. Oxford: Oxford University Press.

47. Marshall, T. (1987). The bicentennial speech. Retrieved from http://thurgoodmarshall.com/the-bicentennial-speech

48. McHugh, J. T. (2002). Comparative constitutional traditions. New York: Peter Lang Publishing.

49. McIlwain, C. H. (1958). Constitutionalism: ancient and modern. New York: Great Seal Books.

50. Mill, J. S. M. (1986). The subjection of women. New York: Prometheus Books.

51. Needler, M. C. (1968). Political development and socioeconomic development: the case of Latin America. American political science review, 62, 889-897.

52. Neubauer, D. E. (1967). Some conditions of democracy. American political science review, 61, 1002-1009.

53. O’Donnell, G., Schmitter, Ph. C., \& Whitehead, L. (Ed.) (1986). Transitions from authoritarian rule. Vol. 4: Tentative conclusions about uncertain democracies (96 p.). Baltimore: Johns Hopkins University Press.

54. Pennock, J. R. (1979). Democratic political theory. Princeton: Princeton University Press.

55. Pennock, J. R., \& Chapman, J. W. (1979). Constitutionalism. New York: NYU Press.

56. Pennock, J. R., \& Chapman, J. W. (1983). Liberal democracy. New York: NYU Press.

57. Posner, D. N., \& Young, D. J. (2010). The institutionalization of political power in Africa. In Diamond, L., \& Plattner, M. F. Democratization in Africa: progress and retreat (pp. 59-72). Baltimore: Johns Hopkins University Press.

58. Powell, G. B. Jr. (2000). Elections as instruments of democracy. New Haven: Yale University Press.

59. Przeworski, A., \& Limongi, F. (1997). Modernization: theory and facts. World politics, 49(2), 155-183.

60. Putnam, R. (1993). Making Democracy Work. Princeton: Princeton University Press.

61. Rabushka, A., \& Shepsle, K. (1972). Politics in plural societies: a theory of democratic instability. Columbus: Merrill Publishers.

62. Rawls, J. (1973). A theory of justice. Cambridge: Belknap Press.

63. Rostow, W. W. (1971). The stages of economic growth. Cambridge: Cambridge University Press.

64. Rousseau, J.-J. R. (1977). The social contract. New York: Penguin.

65. Rueschemeyer, D., Stephens, E. H., \& Stephens, J. (1992). Capitalist development and democracy. Chicago: University of Chicago Press.

66. Rustow, D. A. (1968). Modernization and comparative politics: prospects in research and theory. Comparative. Politics, 1, 37-51.

67. Sartori, G. (1987). The theory of democracy revisited (270 p.). Vol. 1-2. Chatham: Chatham House Publishers.

68. Schultz, D. A. (2002). The phenomenology of democracy: putnam, pluralism, and voluntary associations. In McLean, S. L., Schultz, D. A., \& Steger, M. B. (Eds.). Bowling alone: critical perspectives on community and bowling alone (pp. 74-98). New York: NYU Press.

69. Tarrow, S. (1996). Making social science work across space and time: a critical reflection on Robert Putnam's Making Democracy Work. American political science review, 90, 389-98.

70. Transparency International (2015). Corruption perceptions index. Retrieved from https://www.transparency.org/cpi2015

71. Van Cranenburgh, O. (2012). Democracy promotion in Africa: an institutional context. In Crawford, G., \& Lynch, G. Democratization in Africa: challenges and prospects (pp. 169-187). New York: Routledge. 